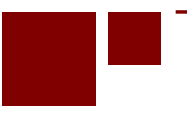

\title{
PARTICIPATION AND PRE-RETIREMENT WITHDRAWALS IN OREGON'S AUTO-IRA
}

\author{
By Laura D. Quinby, Alicia H. Munnell, Wenliang Hou, Anek Belbase, \\ and Geoffrey T. Sanzenbacher
}

CRR WP 2019-15

November 2019

Revised: February 2020

\author{
Center for Retirement Research at Boston College \\ Hovey House \\ 140 Commonwealth Avenue \\ Chestnut Hill, MA 02467
}

Tel: 617-552-1762 Fax: 617-552-0191

https://crr.bc.edu

\begin{abstract}
All of the authors are with the Center for Retirement Research at Boston College (CRR). Laura D. Quinby is a research economist. Alicia H. Munnell is director and the Peter F. Drucker Professor of Management Sciences at Boston College's Carroll School of Management. Wenliang Hou is a senior research advisor. Anek Belbase is a research fellow. Geoffrey T. Sanzenbacher is a research fellow and an associate professor of the practice of economics at Boston College. The research reported herein was derived in whole or in part from research activities performed pursuant to a grant from the U.S. Social Security Administration (SSA) funded as part of the Retirement and Disability Research Consortium. The opinions and conclusions expressed are solely those of the authors and do not represent the opinions or policy of SSA, any agency of the federal government, or Boston College. Neither the United States Government nor any agency thereof, nor any of their employees, make any warranty, express or implied, or assumes any legal liability or responsibility for the accuracy, completeness, or usefulness of the contents of this report. Reference herein to any specific commercial product, process or service by trade name, trademark, manufacturer, or otherwise does not necessarily constitute or imply endorsement, recommendation or favoring by the United States Government or any agency thereof.
\end{abstract}

(C) 2020, Laura D. Quinby, Alicia H. Munnell, Wenliang Hou, Anek Belbase, and Geoffrey Sanzenbacher. All rights reserved. Short sections of text, not to exceed two paragraphs, may be quoted without explicit permission provided that full credit, including (C) notice, is given to the source. 


\begin{abstract}
About the Center for Retirement Research
The Center for Retirement Research at Boston College, part of a consortium that includes parallel centers at the National Bureau of Economic Research, the University of Michigan, and the University of Wisconsin-Madison, was established in 1998 through a grant from the U.S. Social Security Administration. The Center's mission is to produce first-class research and forge a strong link between the academic community and decision-makers in the public and private sectors around an issue of critical importance to the nation's future. To achieve this mission, the Center conducts a wide variety of research projects, transmits new findings to a broad audience, trains new scholars, and broadens access to valuable data sources.
\end{abstract}

Center for Retirement Research at Boston College

Hovey House

140 Commonwealth Avenue

Chestnut Hill, MA 02467

Tel: 617-552-1762 Fax: 617-552-0191

https://crr.bc.edu

Affiliated Institutions:

The Brookings Institution

Mathematica - Center for Studying Disability Policy

Syracuse University

Urban Institute 


\begin{abstract}
About half of private sector workers in the United States do not participate in an employer-sponsored retirement plan at their current job. To fill the gap, a number of state governments around the country have recently launched initiatives to automatically enroll their uncovered workers in Individual Retirement Accounts (IRAs). This paper reports on the experience of Oregon, which was the first state to launch an auto-IRA program (OregonSaves). Because the program only began in July of 2017 and is in its infancy, analysts are still debating basic statistics about its operation, such as the participation rate. To advance the conversation, this study uses administrative data from OregonSaves to develop a conceptual framework for measuring participation. It then shifts the focus to pre-retirement withdrawals, tracking a cohort of employees, who had funded accounts in September 2018, over a 12-month period.
\end{abstract}

The results show that:

- Participation in OregonSaves ranges from 48 to 67 percent; the exact rate is uncertain due to data limitations.

- Twenty percent of employees with balances in September 2018 made at least one preretirement withdrawal during the subsequent year, removing $\$ 1,000$ on average.

- Withdrawals were more likely when employees left their OregonSaves employer relative to full-year contributors (32 and 17 percent of employees, respectively).

The policy implications of the findings are:

- Most eligible employees participate in Oregon's auto-IRA.

- It is not yet clear whether participants will primarily use their accounts for retirement or precautionary savings.

- It is still too early to draw conclusions about the program's overall effect on household finances. 


\section{Introduction}

In recent years, about half of private sector workers in the United States participated in an employer-sponsored retirement plan at their current job (Dushi, Iams, and Lichenstein 2015). ${ }^{1}$ The lack of coverage for the remaining half has troubled policymakers for decades because most Americans arrive at retirement with few financial assets outside of their workplace plans, and, workers who cycle in and out of coverage enter retirement with only a fraction of the savings that they could have accrued had they participated fully. ${ }^{2}$ Federal policy has tried to close the coverage gap by easing regulatory hurdles for firms interested in sponsoring a workplace plan, but this approach has not moved the needle.

Concluding that the federal government is unlikely to enact legislation to increase coverage, several state governments around the country have recently launched initiatives to enroll their uncovered workers. While the shape of these initiatives varies from state to state, most new legislation requires employers to automatically enroll their uncovered workers in an Individual Retirement Account (IRA) from which participants can opt-out at any point. This auto-IRA model - currently adopted by California, Connecticut, Illinois, New Jersey and Oregon - precludes employer matching contributions and also exempts employers from the fiduciary, reporting, and disclosure responsibilities of the Employee Retirement Income Security Act (ERISA). ${ }^{3}$

This paper reports on the experience of Oregon, which was the first state to launch an auto-IRA program in July of 2017 (OregonSaves). Because the program is still in its infancy, analysts are still debating basic statistics about participation and opt-out rates. To advance the conversation, the first section of this study develops a conceptual framework for measuring participation. It finds that participation in OregonSaves ranged from 48 to 67 percent in September 2019, depending on the interpretation of missing data.

The second section of this study shifts the focus to pre-retirement withdrawals. Studies of traditional retirement accounts find that 4 to 8 percent of participants make early withdrawals

\footnotetext{
${ }^{1}$ The exact participation rate has proved difficult for researchers to pin down due to differences across datasets. See Biggs (2016) for a discussion of the difficulties.

${ }^{2}$ Biggs, Munnell, and Chen (2019).

${ }^{3}$ Employer exemption from ERISA is the subject of ongoing litigation. In Maryland, legislation states that employers without a retirement plan "should" automatically enroll employees in a state program, but does not impose financial penalties if firms choose not to. See Georgetown Center for Retirement Initiatives (2019) for details.
} 
from their accounts each year. ${ }^{4}$ However, employees may be more likely to make pre-retirement withdrawals from state auto-IRAs because the programs have been set up as Roth accounts with post-tax contributions, and because participants are likely to have lower incomes and less-stable employment than their counterparts in traditional plans, characteristics that have been shown to increase withdrawals. ${ }^{5}$ Indeed, many workers affected by auto-IRAs have limited liquidity with which to buffer financial shocks, and could benefit from an auto-IRA program even if they occasionally use it as a precautionary savings account. ${ }^{6}$

Using administrative data provided by OregonSaves, the empirical analysis identifies a cohort of current and former participants, who all had funded accounts in September 2018, and tracks this cohort over the subsequent 12 months. It finds that 20 percent of employees made at least one withdrawal during the year, removing $\$ 1,000$ on average. Consistent with prior literature, withdrawals were more frequent when employees left their OregonSaves employer, relative to participants who made payroll deductions in all 12 months (32 and 17 percent of employees, respectively). The analysis finds no significant patterns by employment type (seasonal and contingent versus full-year), wage level, industry, or age.

The final section concludes that much is still unknown about employee behavior in autoIRAs, and it is still too early to draw meaningful conclusions about program outcomes in the long run.

\section{Background on OregonSaves}

In 2015, the Oregon legislature enacted the state's auto-IRA program, OregonSaves, to provide retirement savings accounts to workers whose employers do not sponsor a plan. ${ }^{7}$ The program mandates that eligible employers automatically enroll their employees in OregonSaves and make payroll deductions on their behalf, but employers do not make matching contributions and are exempt from ERISA requirements. To implement the program, the state of Oregon

\footnotetext{
${ }^{4} 1$ to 3 percent of assets under management are withdrawn before retirement each year. See Bryant, Holden, and Sabelhaus (2011); Butrica, Zedlewski, and Issa (2010); Munnell and Webb (2015); Sabelhaus (2000); U.S. Government Accountability Office (2009); and Vanguard (2018). Pre-retirement withdrawal rates depend on the data used in the study - self-reported survey data, tax data, or plan administrative data - and the time period. ${ }^{5}$ Contributions to Roth IRAs can always be withdrawn tax-free, although investment earnings are still sometimes subject to income taxes and penalties, depending on whether the account holder is younger than $591 / 2$ and the account is less than five years old. See Amromin and Smith (2003); Argento, Bryant, and Sabelhaus (2014); and Engelhardt (2003) for the factors that contribute to pre-retirement withdrawals from traditional plans.

${ }^{6}$ See Beshears et al. (2019) and Center for Retirement Research at Boston College (2016).

${ }^{7}$ HB 2960 enrolled.
} 
contracts a Third-Party-Administrator (TPA) in the private sector to identify target employees, set up retirement accounts on their behalf, administer the accounts once established, and facilitate payroll deductions with employers. Initially, employers faced no penalties if they refused (or forgot) to cooperate; starting in January 2020, the state imposes an annual fine of $\$ 100$ per employee, capped at $\$ 5,000$ per year, on employers who neglect to transfer their payroll records to the TPA.

Importantly, participation in OregonSaves is voluntary for employees, who can stop contributing at any point. Employees are defaulted into the program and must make an active decision to halt payroll deductions. Legislators focused on automatic enrollment because only 14 percent of households contribute to IRA accounts outside of state programs, and numerous studies have shown that employees in private sector $401(\mathrm{k})$ plans are very responsive to plan defaults. $^{8}$

Program rollout for firms without a retirement plan is ongoing in waves. The first wave consisted of a self-selected group of pilot employers that did not already offer a retirement plan so that the state and the TPA could iron out kinks in recordkeeping and implementation. Firms with 100 or more employees were required to register by November 2017. Firms with 50 or more employees had to register by May 2018, followed by firms with 20-49 employees by December 2018. ${ }^{9}$ The registration deadline for firms with 10-19 employees was May 2019, and the deadline for firms with 5-9 employees was November 2019. Remaining small employers must register no later than January 2021.

After employers have responded to OregonSaves' requirement to register, they have 30 days in which to provide employee information to the program. Employers with electronic payroll systems can configure their systems to periodically transfer information, while those without payroll systems manually enter information into an online portal. OregonSaves then sends a notice to eligible employees, informing them that they will be automatically enrolled in the program unless they opt out within 30 days. At the end of the 30-day window, employers

\footnotetext{
${ }^{8}$ Chen and Munnell (2017) describe participation in IRA accounts. Although only 14 percent of households contribute, IRAs hold nearly half of all assets in private sector retirement plans because many workers roll over their 401(k) balances when they change employers. Legislators hoping to increase participation in state plans relied on studies of automatic enrollment in 401(k)s; for example, see Carroll et al. (2009); Cribb and Emmerson (2019); and Madrian and Shea (2001). Of course, these studies may overestimate the power of automatic enrollment in autoIRAs because workers eligible for a 401(k) tend to have higher incomes and more stable employment.

${ }^{9}$ Smaller employers are permitted to register early.
} 
have an additional 30 days in which to set up automatic payroll deductions (see Figure 1 for the registration timeline).

The initial deadlines for employer participation in OregonSaves were largely aspirational since the state lacked data on what a reasonable timeline should look like, and the employers affected had no experience offering a retirement plan on their own. Figure 2 shows that nearly 8,000 employers had registered with OregonSaves as of September 2019, but that only 3,039 of

them were facilitating payroll deductions on behalf of their employees. ${ }^{10}$ Of the firms processing payroll, 65 percent were in the services and restaurant industries, while an additional 20 percent were in retail and manufacturing (see Table 1). Participating firms were also fairly small; half of the employers processing payroll had 10-25 employees, and 87 percent had 50 employees or fewer (see Table 2).

Employees are defaulted into the program at a 5-percent deferral rate. This default increases by one percentage point per year until the contribution rate reaches 10 percent of hourly wage. ${ }^{11}$ To ensure that workers who opt out of the program late fully recover their contributions, participants are defaulted into Roth IRA accounts (which are funded with after-tax money) and the first $\$ 1,000$ in an employee's account is defaulted into a capital preservation fund. The remainder is invested in a target-date fund. ${ }^{12}$

\section{Measuring Participation in OregonSaves}

As OregonSaves enters its third year, policymakers have begun to evaluate the level of employee participation. Answering this seemingly straightforward question turns out to be complicated because of the ongoing rollout and the many ways in which workers can leave and re-enter the program. As a result, analysts have cited participation rates ranging from as low as 27 percent to as high as 67 percent. $^{13}$ The goal of this section is to develop a conceptual

\footnotetext{
10 The reasons for the gap are still poorly understood.

11 The automatic escalation of the default deferral rate is intended to provide an 80-percent replacement rate (combined with Social Security) to a typical program participant entering OregonSaves at age 25 and retiring at age 67.

12 The Oregon Retirement Savings Board charges each IRA account an annual administrative fee capped at 1.05 percent (Georgetown Center for Retirement Initiatives 2019).

${ }^{13}$ Chalmers et al. (2019) report that 27 percent of eligible workers had contributed to their accounts by April 2019 , and an additional 29 percent were waiting to make their first contribution. Belbase and Sanzenbacher (2018) report that 67 percent of eligible workers had either contributed or set a positive payroll deduction rate as of December, 2018 , but the authors do not specify how many of these workers had assets in their accounts.
} 
framework for measuring participation that explains this range of results. ${ }^{14}$ The conceptual framework will also help define the sample for the analysis of pre-retirement withdrawals in the next section.

Figure 3 presents this conceptual framework as a flow chart. Employees first engage with OregonSaves in the upper-left corner of the chart, through employers that have registered with the program. As of September 1, 2019, OregonSaves had set up accounts for 190,220 workers, representing 203,394 distinct employment relationships. ${ }^{15}$

Employees are not able to participate in the program until their employer makes payroll deductions on their behalf. The first downward arrow on the flow chart shows how the universe of potential participants shrinks once employer engagement is taken into account. Of the 203,394 registered employees above, only 159,257 were with employers who were processing payroll deductions on September 1, 2019. From here, the flow chart begins to move to the right. Employees who terminate their relationship with all OregonSaves employers before September 2019 also cannot participate in the program, resulting in 82,663 "active employees" who are eligible to begin deducting payroll contributions. This group of eligible employees forms the denominator of the participation rate. ${ }^{16}$

Eligible employees can choose not to participate through two mechanisms. First, they can opt out during the initial 30-day window, and 31 percent choose to do so (the bottom right corner of the flow chart). ${ }^{17}$ Eligible employees who do not opt out are considered "enrolled." Some enrolled employees still do not save through the program because they set their deferral rate to zero and withdraw their balances. Figure 3 shows that 2 percent of eligible employees do not participate through this mechanism. Taken together with the opt-out rate, these results suggest a participation rate in OregonSaves of 67 percent. However, it turns out that only 48 percent of eligible employees actually have positive balances. The difference is due to a

\footnotetext{
${ }^{14}$ Surprisingly, a large literature on pension participation does not yet have a common definition for participation. The three definitions typically used include: 1) having a positive account balance at one's current employer; 2) responding affirmatively to the question "are you participating?"; and 3) currently making contributions to a plan (see Turner, Muller, and Verma 2003).

${ }^{15}$ Since so few workers engage with OregonSaves through multiple employers simultaneously, the rest of this section focuses on employment relationships.

${ }^{16}$ Note that some inactive employees as of September 1, 2019 have positive account balances from past participation in the program; these employees do not affect the current participation rate, but will factor into the analysis of pre-retirement withdrawals. Employees whose accounts are still pending are also considered ineligible to participate.

${ }^{17}$ A very small fraction of eligible employees in the administrative data report positive account balances and opt-out dates after the initial 30-day window.
} 
significant group of employees who look like they should be accumulating assets (eligible to participate with a positive deferral rate) but are missing data on the amount of their balances.

In summary, as of the most recent data available, participation in OregonSaves ranged from 48 percent to 67 percent. Figure 4 replicates the analysis in each month between September 2018 and September 2019, and shows that this participation-rate range has held steady for at least a year. Moreover, the conceptual framework outlined in Figure 3 teaches two lessons about measuring participation. First, the denominator of the participation rate should only include employees who are actually eligible to make payroll deductions (active at an employer processing payroll). Second, participation may not simply be the inverse of the opt-out rate because some employees inexplicably lack balances. Improving data quality is clearly a first-order research priority.

\section{Do Participants Use OregonSaves for Precautionary Saving?}

Measuring participation is a necessary first step in evaluating OregonSaves, but it does not tell the full story. If employees are to accrue meaningful retirement savings, they must not only make consistent payroll deductions, but also keep their assets in the program. This phase of the analysis addresses the second question of pre-retirement withdrawals. Prior studies of traditional 401(k)s and IRAs often refer to these transactions as "leakages," defined as withdrawals made before retirement that are not rolled over to another retirement account. This study adopts the more cumbersome term "pre-retirement withdrawal" because "leakage" has negative connotations that may not be relevant in the auto-IRA setting. Indeed, low-income workers with weak labor force attachment could benefit from the program even if they occasionally withdraw money for immediate expenditures. The preliminary results in this study suggest that many employees may use the program for precautionary saving, but OregonSaves is still very new and analysts cannot yet draw firm conclusions about employee behavior in a mature program.

Since most prior studies of pre-retirement withdrawals focus on traditional retirement plans (whereas OregonSaves is a Roth IRA) it is useful to consider how plan structure could affect precautionary savings before diving into the empirical analysis. Traditional plans and Roth IRAs provide nearly identical tax benefits to workers who leave their savings in the plan 
until retirement. ${ }^{18}$ However, participants may be more likely to use Roth IRAs for precautionary saving because of the tax treatment of early withdrawals. Since contributions to traditional plans are made on a pre-tax basis, participants in these plans who wish to cash out their savings must either document financial hardship or experience a job change. Both forms of pre-retirement withdrawals are often subject to a 10-percent tax penalty in addition to regular income taxes. ${ }^{19}$ In contrast, contributions to Roth IRAs are made on a post-tax basis, and participants can withdraw their contributions at any point without a tax penalty. ${ }^{20}$ Consequently, pre-retirement withdrawals from OregonSaves might be more prevalent than from traditional plans even if the population covered were the same.

\section{Empirical Analysis}

To investigate pre-retirement withdrawal patterns in OregonSaves, this study focuses on workers under age 60 who had positive account balances on September 1, 2018 and tracks these workers over a 12-month period. ${ }^{21}$ The sample includes participating employees as well as a few workers who are no longer employed at a participating employer (inactive employees), but who have positive balances from past employment. The September 2018 starting date is chosen to allow mid-size employers - who should have registered by May 2018 - sufficient time to start making payroll deductions. Ultimately, the analysis tracks 16,915 accounts held by 17,650 employees.

\footnotetext{
${ }^{18}$ See Munnell (2003) for a detailed comparison of Roth and traditional IRAs.

${ }^{19}$ In-service hardship withdrawals from a 401(k) can be used to pay for medical expenses, funeral expenses, home purchases (including to prevent eviction from, or mortgage foreclosure on, the principal residence; the purchase of a first home, and repairs to the principal residence), and postsecondary tuition. Traditional IRAs also allow hardship exemptions to pay for health insurance if unemployed for at least 12 weeks, and up to $\$ 10,000$ for a first home purchase. Technically, employees claiming financial hardship must document that they have exhausted other funds. Employees can only withdraw contributions to the account, not investment earnings. IRA accounts exempt many of the hardship withdrawals from the 10-percent tax penalty, and employees over age 591/2 can make in-service withdrawals for non-hardship reasons from either type of account without experiencing a tax penalty. In addition to the penalty, distributions at job change are also subject to a 20-percent withholding tax that is credited against future federal and state tax liabilities. Employees who do not take a lump sum can either roll over their balance to an IRA or transfer it to a new $401(\mathrm{k})$ if the new plan accepts rollovers.

${ }^{20}$ Investment earnings withdrawn are still subject to income taxes and the 10-percent penalty unless: 1) the account is more than five years old, and; 2) the distribution is qualified (used to buy or rebuild a first home or is due to death or disability), or; 3) the account holder is older than $59^{1 / 2}$.

${ }^{21}$ The definition of pre-retirement withdrawals varies across studies, with some only classifying withdrawals before age 55 as pre-retirement and others including withdrawals made after age 55 . This study splits the difference and sets "retirement" at age 60 , but the empirical results are not sensitive to this choice.
} 
Before taking a detailed look at pre-retirement withdrawals, the analysis first addresses two simple questions: how many employees in the sample made a withdrawal during the year, and how much did they remove from their accounts? The answer to the first question is shown in Figure 5, which reveals that 20 percent of employees in the sample made at least one withdrawal during the year, corresponding to two percent of employees each month. Most employees who withdrew funds only did so once during the year (14 percent of the total sample), while 3 percent of the sample made two withdrawals, and the remaining 3 percent made regular withdrawals every few months. Among employees who made a withdrawal, the amount averaged $\$ 1,000 .^{22}$ Although it is tempting to divide assets withdrawn by pre-withdrawal account balances, this comparison could be misleading because balances in the nascent program are still extremely low. ${ }^{23}$ Analysts may wish to monitor pre-retirement withdrawals over the next few years before drawing firm conclusions about the rate at which assets leave the program. Similarly, more years of data are needed to determine whether employees primarily use their accounts for precautionary saving or retirement.

Nevertheless, policymakers may wish to know whether specific types of employees were more likely to make a withdrawal during the analysis period. As described earlier, participating employees have two mechanisms for ending their relationship with OregonSaves. They can change jobs and move to a non-participating employer, or they can set their deferral rate to zero. Either form of disengagement might trigger a withdrawal. To explore this possibility, Table 3 sorts the sample into five mutually exclusive groups:

1) Employees who made payroll deductions for 12 consecutive months ("full-year contributors");

2) Employees who stayed in their jobs with a positive deferral rate, but still did not contribute consistently because of seasonal or contingent employment ("part-year contributors");

3) Employees who stayed in their jobs, but set their deferral rate to zero at some point during the year ("active non-savers");

4) Employees who left OregonSaves during the year because they changed jobs ("job changers"); and

\footnotetext{
${ }^{22}$ Overall, withdrawals over the 12-month period equaled nearly 20 percent of total pre-withdrawal balances.

${ }^{23}$ For example, making emergency car repairs might cost $\$ 1,000$. In three years, the car repair will still cost roughly $\$ 1,000$, but the average balance will have grown exponentially.
} 
5) Employees who were already inactive in September 2018 with account balances ("full-year inactives").

The list is sorted by degree of participation, since full-year contributors had the strongest attachment to the program during the analysis period while full-year inactives were not even eligible to participate. Table 3 shows that full-year contributors comprised 25 percent of the sample and part-year contributors an additional 23 percent. Only 12 percent of the sample were active non-savers, while 28 percent were job changers. The remaining 13 percent fell into the full-year inactive category. Consequently, 40 percent of the sample disengaged from OregonSaves during the analysis period.

Figure 6 calculates the fraction of employees in each group that withdrew funds during the year. As expected, job changers were disproportionately likely to make a withdrawal relative to other categories. Thirty-two percent of job changers made at least one withdrawal during the year, compared to 17 percent of full-year contributors and 21 percent of part-year contributors. However, only 3 percent of active non-savers withdrew funds during the year, which is a much lower propensity than other groups. Similarly, only 10 percent of full-year inactives made a withdrawal during the year, suggesting that many pre-retirement withdrawals may occur in close proximity to a job change. It is interesting to note that full-year contributors, part-year contributors, and job-changers were responsible for 97 percent of the total funds withdrawn during the year (see Figure 7).

The next question is whether employee demographics predict pre-retirement withdrawals. Although Oregon's administrative data do not report many demographic characteristics, it is possible to categorize employees by earnings, industry, and age. Specifically, the analysis calculates earnings for those who made at least one payroll deduction by dividing the contribution by the employee's deferral rate. ${ }^{24}$ While this measure misses employees who did not make any deductions during the year, labor income outside of OregonSaves, and all nonlabor income, it nevertheless serves as a rough proxy for monthly earnings. Figure 8 compares the fraction of employees making withdrawals across earnings terciles. Employees in the bottom tercile had monthly earnings below $\$ 1,300$ and a 20 -percent probability of making a withdrawal.

\footnotetext{
${ }^{24}$ The wage base is averaged across the year for employees who make multiple payroll deductions. Employees missing a deferral rate in the data are assumed to deduct the default rate of 5 percent.
} 
Employees in the top tercile, meanwhile, earned at least $\$ 2,400$ per month and had a 27-percent probability of making a withdrawal. However, one should not draw strong conclusions from this result because employees with very low wages could have primary employment outside of OregonSaves and face relatively little financial stress. The most likely interpretation is that earnings are not a strong predictor of pre-retirement withdrawals.

Table 4, which sorts employees by industry, also yields little insight. Employees in farming, retail, and restaurants - three industries that rely on seasonal workers and have relatively unstable wages - were no more likely to withdraw funds than employees in the "services" industry, which includes religious and health-care organizations. Employees in manufacturing and temporary help agencies may have been slightly less likely to withdraw than other industries, but without more years of data it is difficult to distinguish true differences from statistical noise. Similarly, Figure 9 shows no meaningful patterns by employee age.

\section{Conclusion}

State auto-IRA programs are intended to improve the economic security of employees who are not covered by a retirement plan at work. To achieve this goal, the programs must encourage eligible employees to participate consistently, while also allowing them to tap their assets when financially stressed.

This study reports on both participation and pre-retirement withdrawals in the second year of Oregon's auto-IRA, OregonSaves. Although straightforward conceptually, measuring participation in OregonSaves is difficult in practice because the program is still rolling out to employers, employee mobility is high, and administrative data are missing key information for some potential participants. Although this study solves the issues of program rollout and employee mobility by developing a clear conceptual framework for measuring participation, it cannot overcome the data limitations. Consequently, it calculates participation rates ranging from 48 percent to 67 percent in September 2019.

To investigate pre-retirement withdrawals, the analysis tracks a cohort of participants throughout the program's second year, finding that 20 percent of employees with beginning-ofyear balances withdrew at least some funds over the subsequent 12 months. Future research could survey workers to ascertain the reason for these withdrawals; in addition to the standard triggers - such as medical expenses and changes in family composition - employees could be 
responding to structural features of OregonSaves. For example, Roth accounts are funded on a post-tax basis and allow contributions to be withdrawn at any point without a tax penalty, while the program's young age means that participants still have very low account balances that might be tempting to spend. Consequently, it is still too early to assess how the program will affect participants' finances. 


\section{References}

Amromin, Gene and Paul Smith. 2003. "What Explains Early Withdrawals from Retirement Accounts? Evidence from a Panel of Taxpayers.” National Tax Journal 56(3): 595-612.

Argento, Robert, Victoria L. Bryant, and John Sabelhaus. 2015. "Early Withdrawals from Retirement Accounts During the Great Recession." Contemporary Economic Policy 33(1): 1-16.

Belbase, Anek and Geoffrey T. Sanzenbacher. 2018. "How Have Workers Responded to Oregon's Auto-IRA?” Issue in Brief 18-22. Chestnut Hill, MA: Center for Retirement Research at Boston College.

Beshears, John, James J. Choi, Mark Iwry, David John, David Laibson, and Brigitte C. Madrian. 2019. "Building Emergency Savings Through Employer-Sponsored Rainy-Day Savings Accounts." Working Paper 26498. Cambridge, MA: National Bureau of Economic Research.

Biggs, Andrew G. 2016. "What's Happening with Retirement Saving and Retirement Incomes? Better Data Tell a Better Story.” Washington, DC: American Enterprise Institute.

Biggs, Andrew G., Alicia H. Munnell, and Anqi Chen. 2019. "Why Are 401(k)/IRA Balances Substantially Below Potential?” Working Paper 2019-14. Chestnut Hill, MA: Center for Retirement Research at Boston College.

Bryant, Victoria L., Sarah Holden, and John Sabelhaus. 2011. "Qualified Retirement Plans: Analysis of Distribution and Rollover Activity." Wharton Pension Research Council Working Paper 165. Philadelphia, PA: University of Pennsylvania.

Butrica, Barbara, Sheila R. Zedlewski, and Philip Issa. 2010. "Understanding Early Withdrawals from Retirement Accounts." The Retirement Policy Program Discussion Paper 10-02. Washington, DC: The Urban Institute.

Carroll, Gabriel D., James J. Choi, David Laibson, Brigitte C. Madrian, and Andrew Metrick. 2009. "Optimal Defaults and Active Decisions." Quarterly Journal of Economics 124(4): 1639-1674.

Center for Retirement Research at Boston College. 2016. "Oregon Market Research Report." Available at: https://www.oregon.gov/retire/SiteAssets/Pages/Newsroom/ORSP\% 20Market\%20Analysis\%2013JULY2016.pdf.

Chalmers, John, Olivia S. Mitchell, Jonathan Reuter, Geoffrey Sanzenbacher, and Mingli Zhong. 2019. "Auto-Enrollment Plans for the People: Choices and Outcomes in OregonSaves." Working paper presented at the $21^{\text {st }}$ Retirement and Disability Research Consortium Annual Meeting. Washington, DC. 
Chen, Anqi, and Alicia H. Munnell. 2017. "Who Contributes to Individual Retirement Accounts?" Issue Brief 17-8. Chestnut Hill, MA: Center for Retirement Research at Boston College.

Cribb, Jonathan and Carl Emmerson. 2019. "Requiring Auto-Enrollment: Lessons from UK Retirement Plans." Issue in Brief 19-6. Chestnut Hill, MA: Center for Retirement Research at Boston College.

Dushi, Irina, Howard M. Iams, and Jules Lichtenstein. 2015. "Retirement Plan Coverage by Firm Size: An Update." Social Security Bulletin 75(2): 41-55.

Engelhardt, Gary V. 2003. "Reasons for Job Change and the Disposition of Pre-Retirement Lump-Sum Pension Distributions.” Economics Letters 81: 333-339.

Georgetown Center for Retirement Initiatives. 2019. "State-Facilitated Retirement Savings Programs: A Snapshot of Program Design Features.” State Brief. Washington, DC.

Madrian, Brigitte C. and Dennis F. Shea. 2001. "The Power of Suggestion: Inertia in 401(k) Participation and Savings Behavior." Quarterly Journal of Economics 116(4): 11491187.

Munnell, Alicia H. 2003. "A Primer on IRAs.” Just the Facts on Retirement Issues 7. Chestnut Hill, MA: Center for Retirement Research at Boston College.

Munnell Alicia H. and Anthony Webb. 2015. "The Impact of Leakages from 401(k)s and IRAs." Working Paper 2015-2. Chestnut Hill, MA: Center for Retirement Research at Boston College.

Sabelhaus, John. 2000. "Modeling IRA Accumulation and Withdrawals." National Tax Journal 53(4): 865-875.

Turner, John and Satyendra K. Verma. 2003. "Defining Participation in Defined Contribution Pension Plans." Monthly Labor Review 126: 36-43.

United States Government Accountability Office. 2009. "401(k) Plans: Policy Changes Could Reduce the Long-term Effects of Leakage on Workers' Retirement Savings." GAO-09715. Washington, DC: Government Printing Office.

Vanguard. 2018. "How America Saves: Vanguard 2018 Defined Contribution Plan Data." Available at: https:/institutional.vanguard.com/VGApp/iip/site/institutional/researchcommentary/articl e/HowAmericaSaves2019 
Table 1. Major Industries Participating in OregonSaves, September 2019

\begin{tabular}{lc}
\hline Industry & Percent \\
\hline Farming & $5.8 \%$ \\
Construction & 6.2 \\
Manufacturing & 7.5 \\
Retail & 12.7 \\
Transport & 1.9 \\
Services & 34.0 \\
Temporary help services & 1.0 \\
Restaurants & 31.0 \\
\hline Total & $100.0 \%$ \\
\hline
\end{tabular}

Note: The table only includes employers that had processed payroll by September 2019 .

Source: Authors' calculations from OregonSaves' data.

Table 2. Distribution of Employers by Number of Employees, September 2019

\begin{tabular}{lc}
\hline Firm size & Percent \\
\hline $100+$ & $4.6 \%$ \\
$50-99$ & 7.7 \\
$20-49$ & 23.4 \\
$10-19$ & 51.2 \\
$<10$ & 12.1 \\
Missing & 1.0 \\
\hline Total & $100.0 \%$ \\
\hline
\end{tabular}

Note: The table only includes employers that had processed payroll by September 2019 .

Source: Authors' calculations from OregonSaves' data.

Table 3. Participation of Employees with Beginning-Year Account Balances, September 2018September 2019

\begin{tabular}{lc}
\hline Participant status & Share of the sample \\
\hline 1) Full-year contributors & $24.7 \%$ \\
2) Part-year contributors & 22.9 \\
3) Active non-savers & 11.6 \\
4) Job changers & 28.0 \\
5) Full-year inactives & 12.9 \\
\hline
\end{tabular}

Source: Authors' calculations from OregonSaves' data. 
Table 4. Percentage of Employees Withdrawing Funds Before Retirement by Industry, September 2018-September 2019

\begin{tabular}{lc}
\hline Industry & Probability of withdrawing \\
\hline Farming & $23.7 \%$ \\
Construction & 24.8 \\
Manufacturing & 15.4 \\
Retail & 20.6 \\
Transport & 23.3 \\
Services & 20.6 \\
Temporary help agencies & 11.9 \\
Restaurants & 20.8 \\
\hline Total & $19.6 \%$ \\
\hline
\end{tabular}

Source: Authors' calculations from OregonSaves' data. 
Figure 1. OregonSaves Rollout: From Registration to Payroll Processing

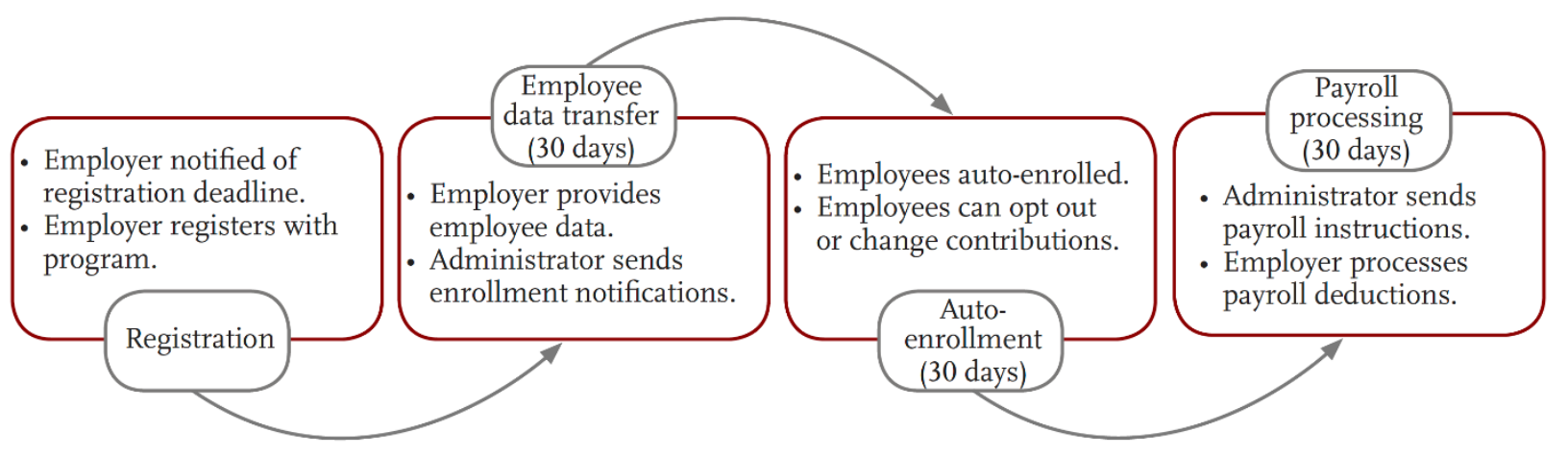

Source: OregonSaves Employer Registration Timeline.

Figure 2. Rollout of OregonSaves to Employers

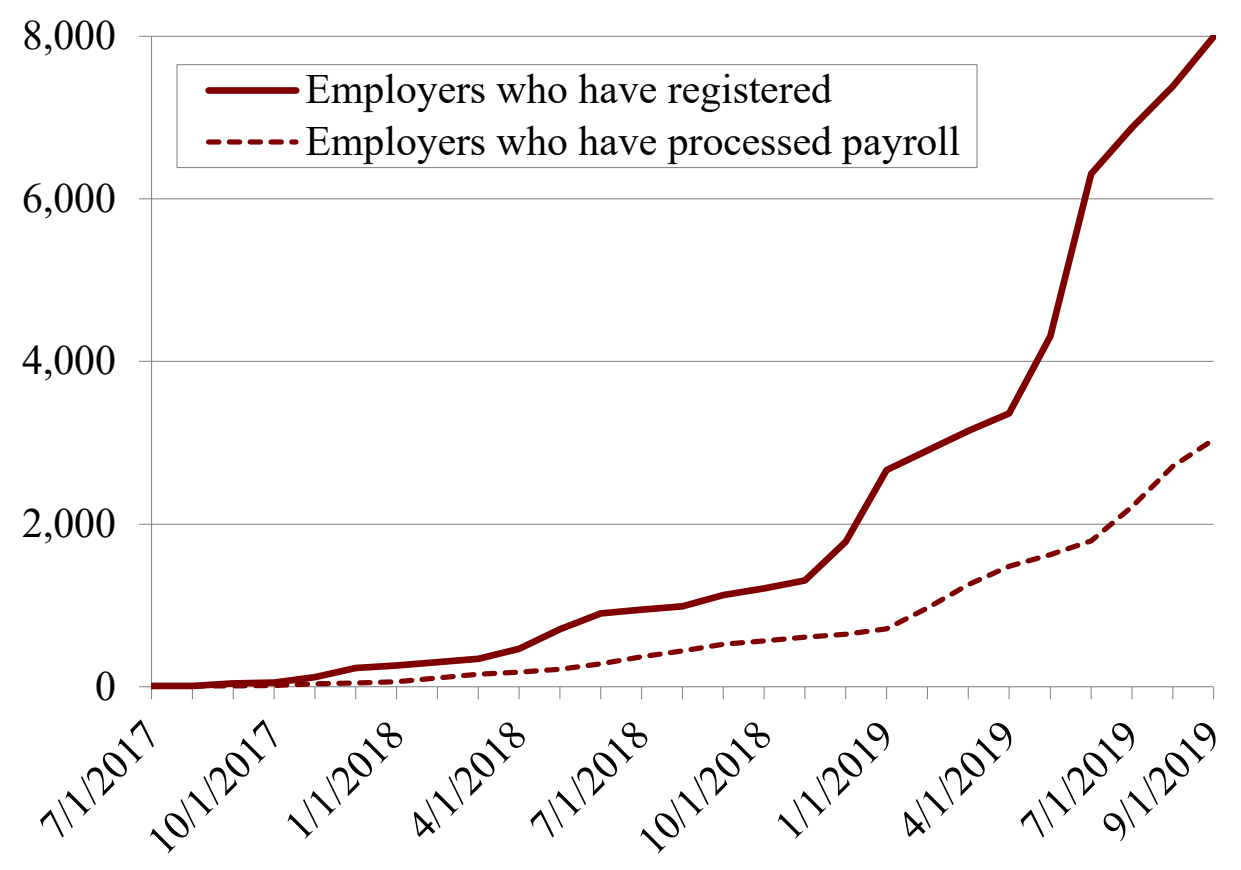

Source: Authors' calculations from OregonSaves' data. 
Figure 3. Conceptual Framework for Measuring Participation, September 2019

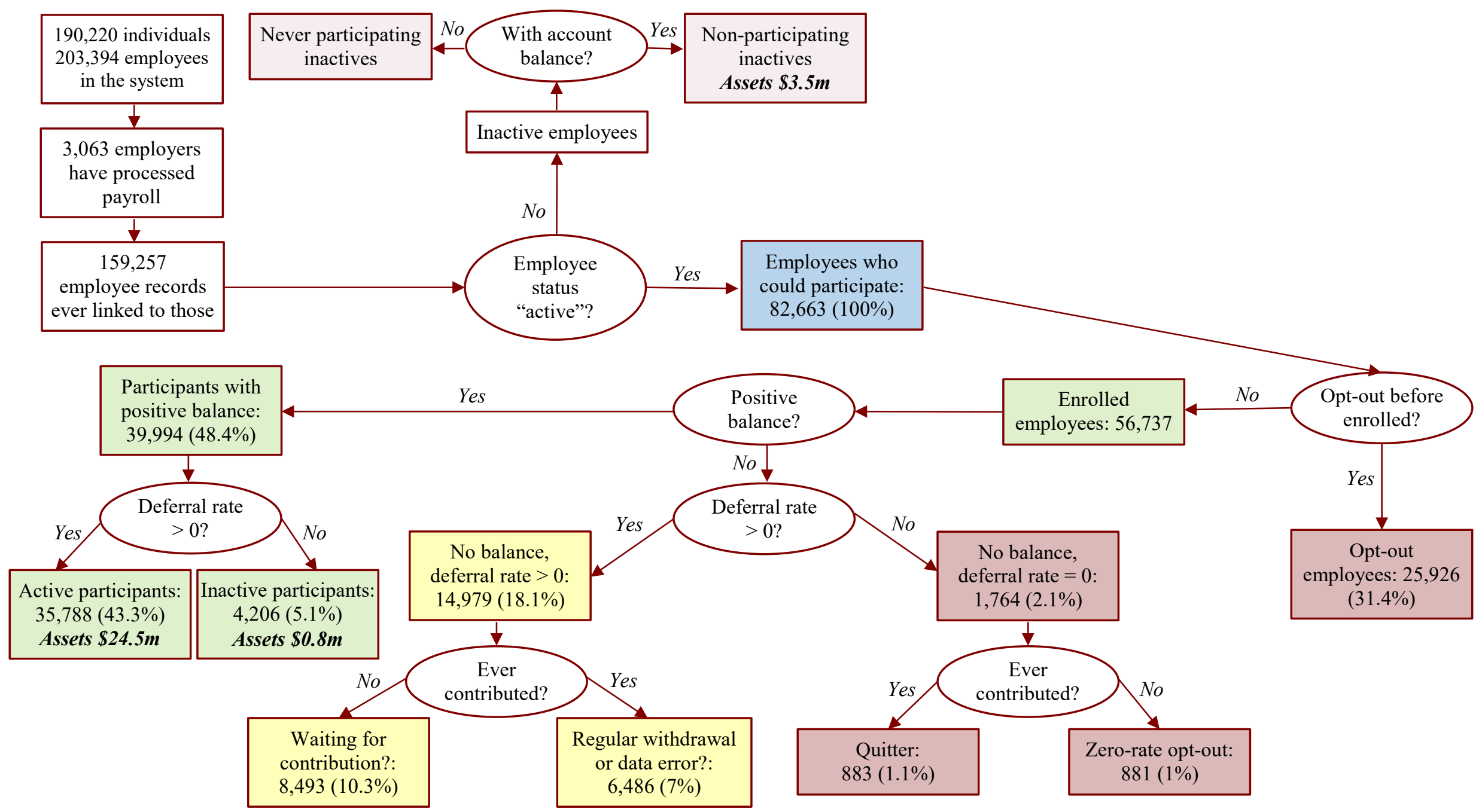

Source: Authors' calculations from OregonSaves' data. 
Figure 4. Participation Rates in OregonSaves, September 2018-September 2019

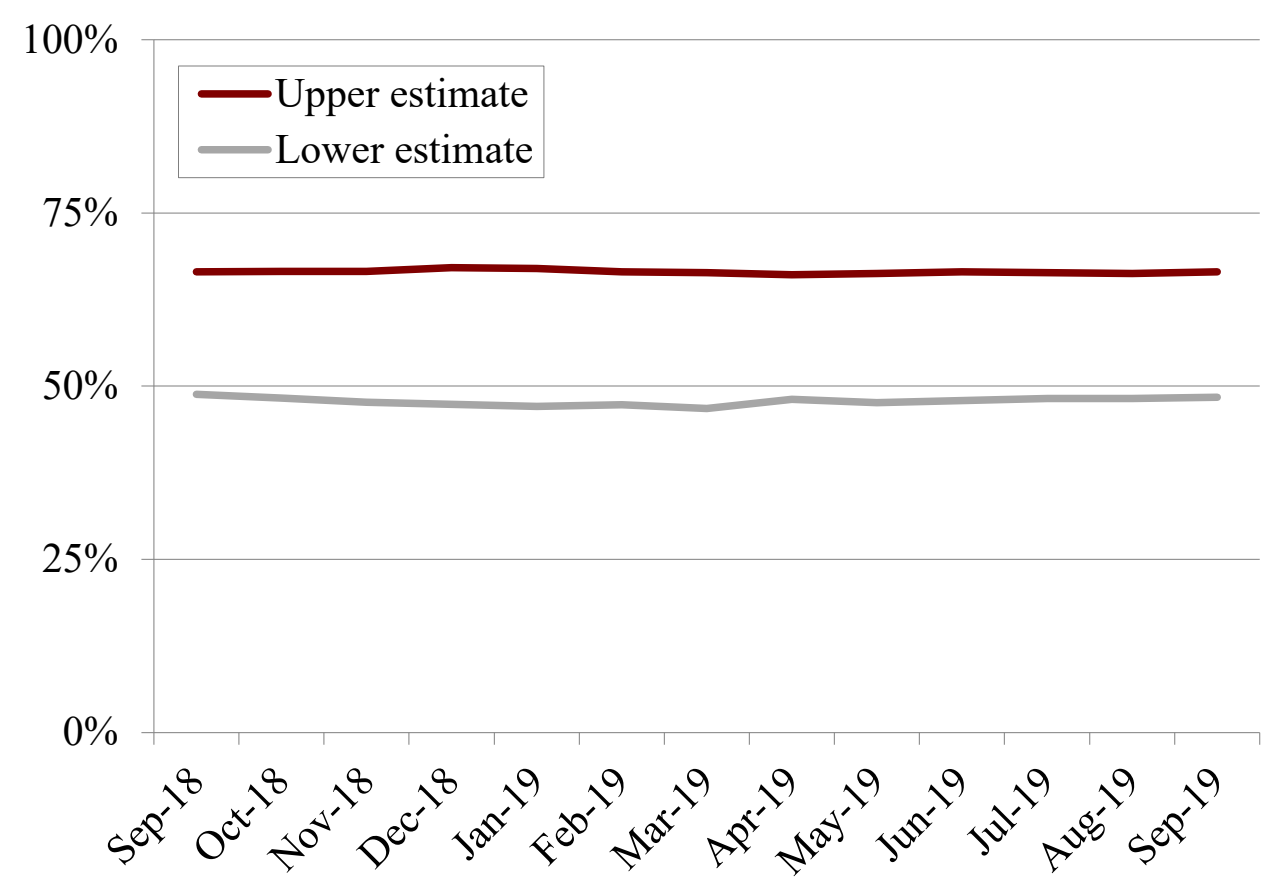

Notes: The denominator of both participation rates includes active employees whose employers are processing payroll deductions. The numerator of the upper estimate includes eligible employees with account balances as well as those who have a positive deferral rate but no account balance. The numerator of the lower estimate only includes eligible employees with positive account balances.

Source: Authors' calculations from OregonSaves' data. 
Figure 5. Percentage of Employees in OregonSaves Making a Pre-Retirement Withdrawal during the Year, September 2018-September 2019

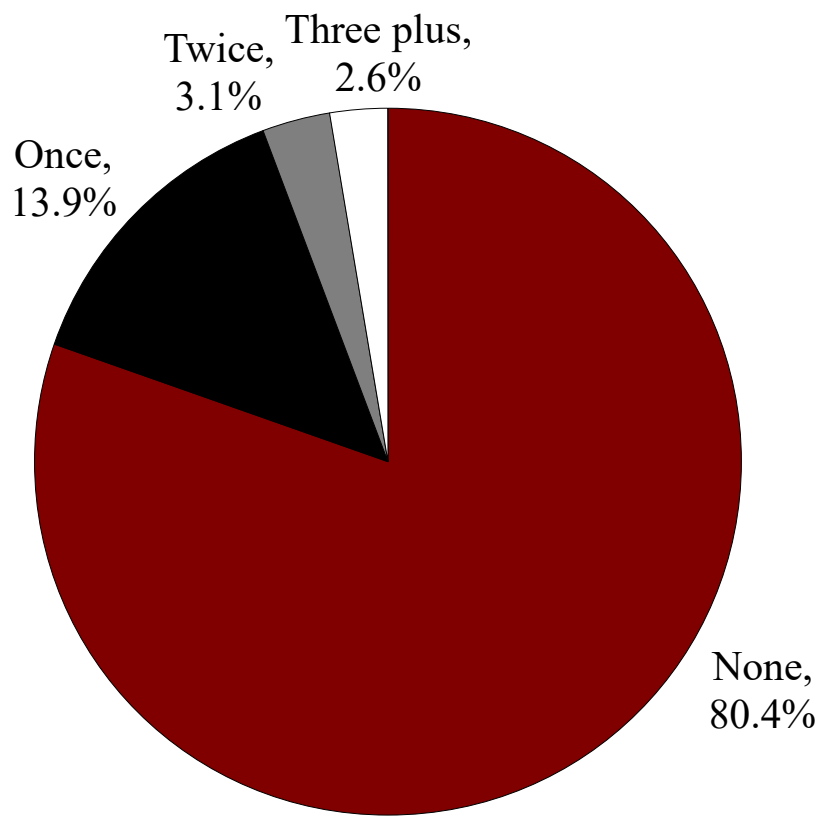

Source: Authors' calculations from OregonSaves' data.

Figure 6. Percentage of Employees Making a Pre-Retirement Withdrawal during the Year, by Participation Status, September 2018-September 2019

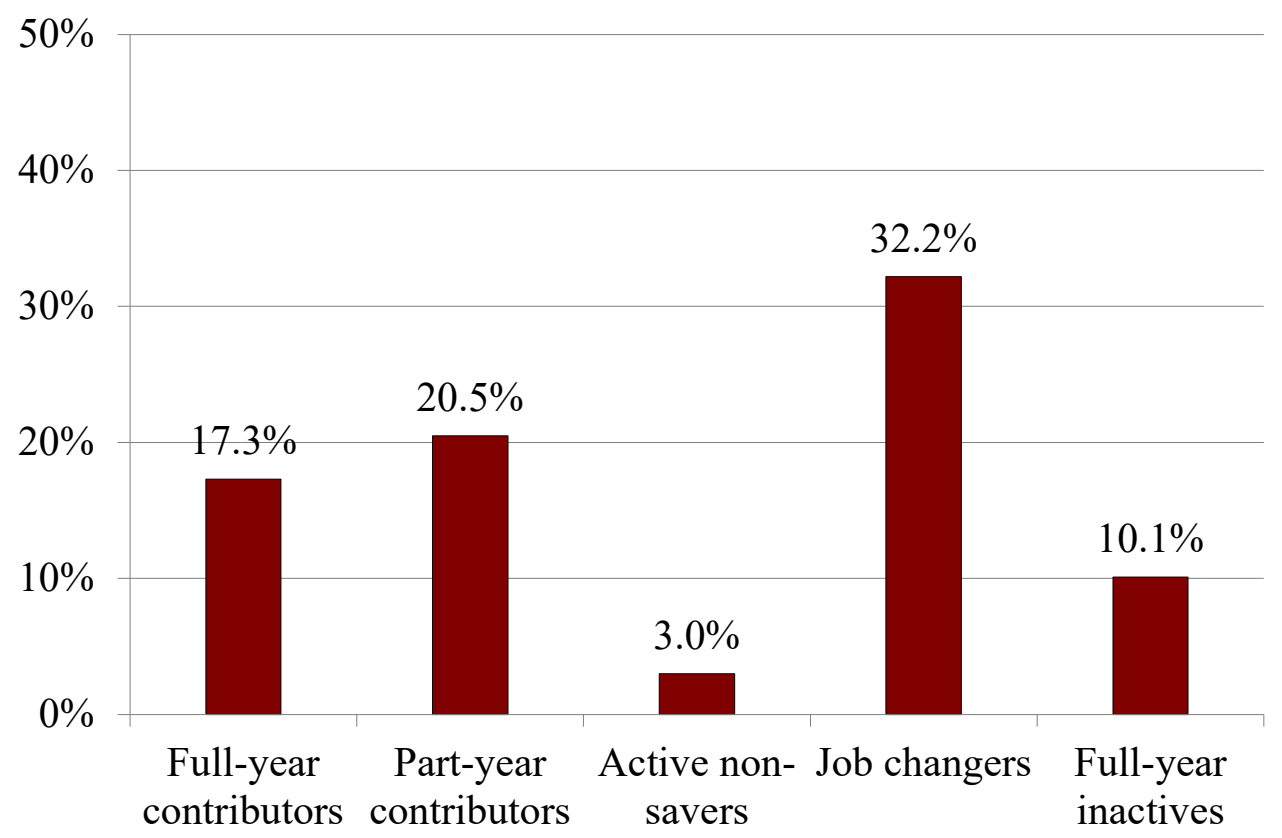

Source: Authors' calculations from OregonSaves' data. 
Figure 7. Total Funds Withdrawn Before Retirement by Source, September 2018-September 2019

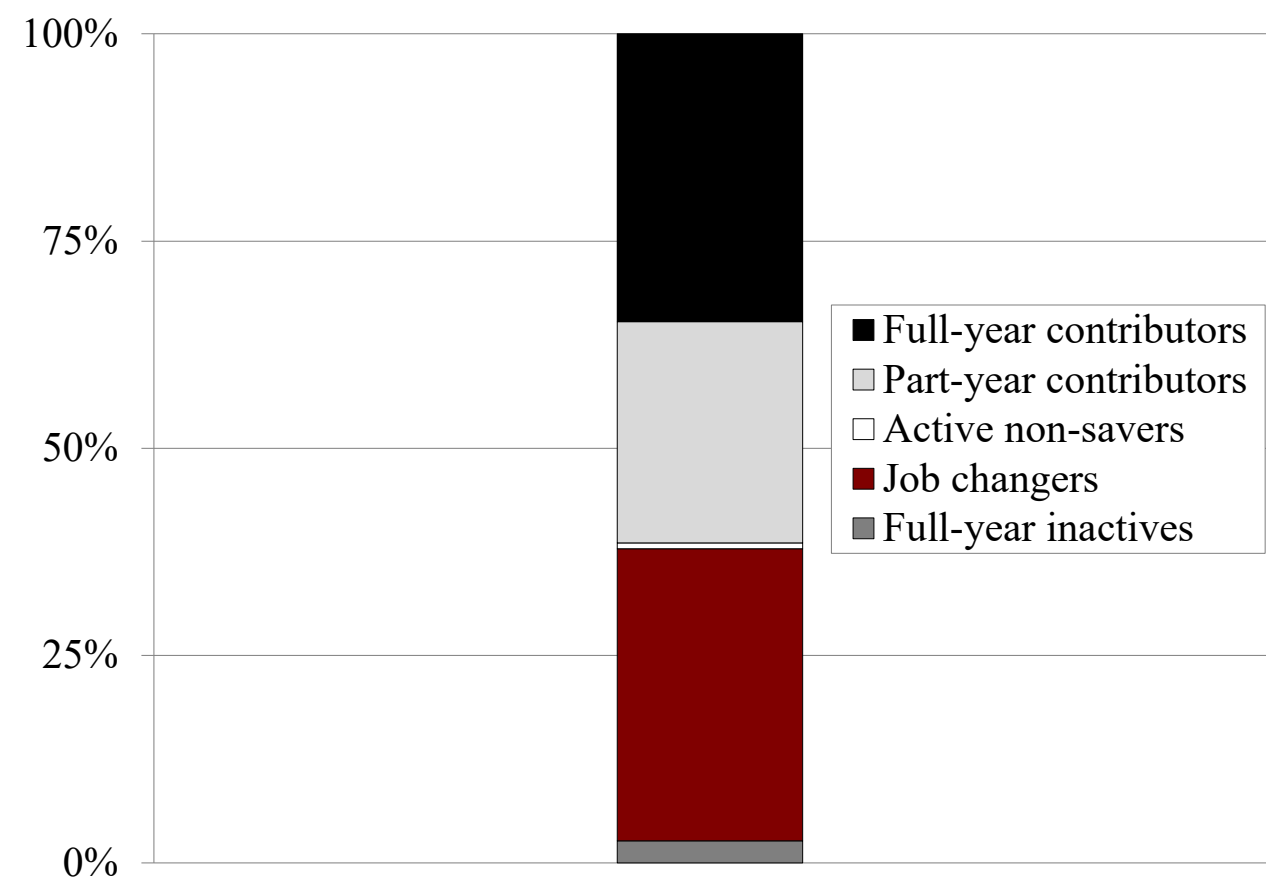

Source: Authors' calculations from OregonSaves' data.

Figure 8. Percentage of Employees Withdrawing Funds Before Retirement by Average Monthly Wage, September 2018-September 2019

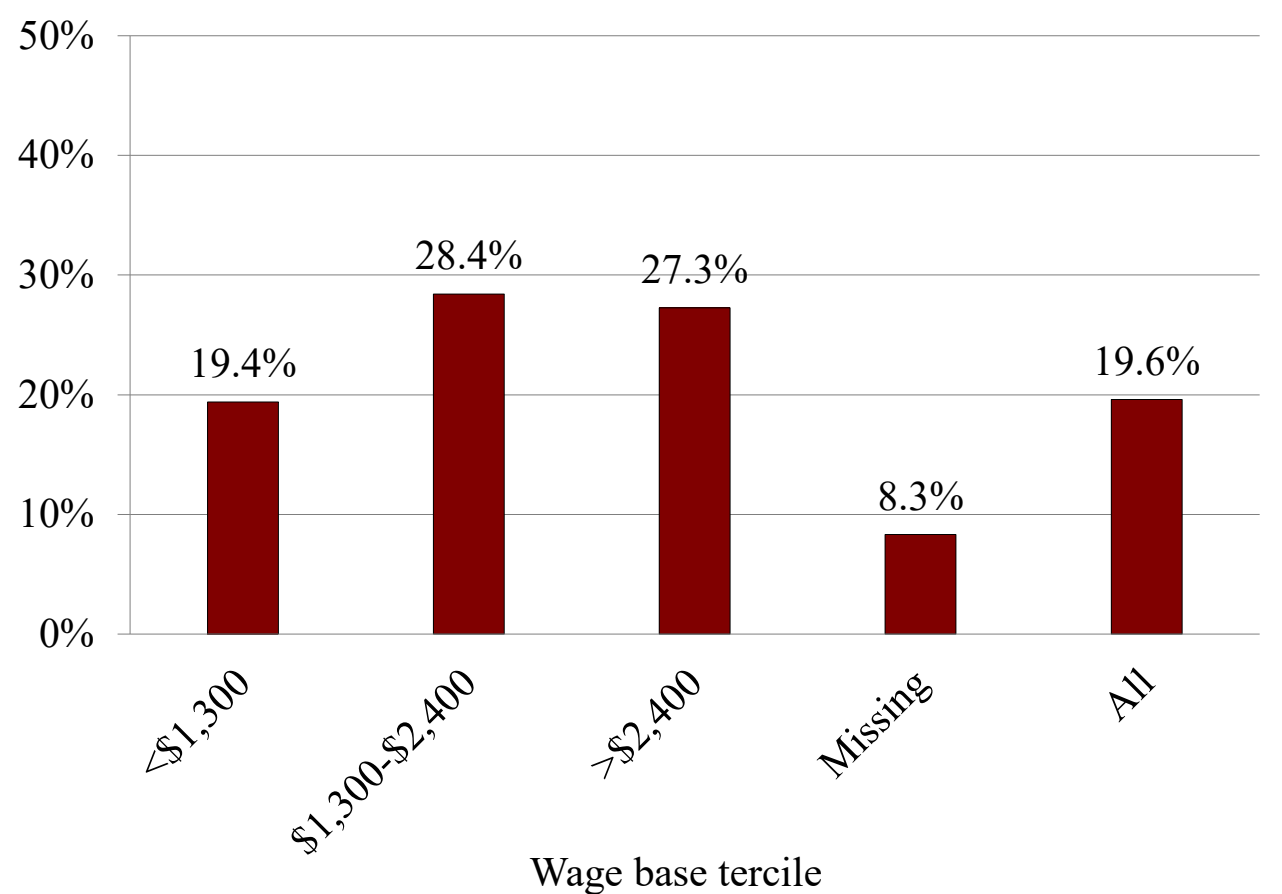

Source: Authors' calculations from OregonSaves' data. 
Figure 9. Percentage of Employees Withdrawing Funds Before Retirement by Age, September 2018-September 2019

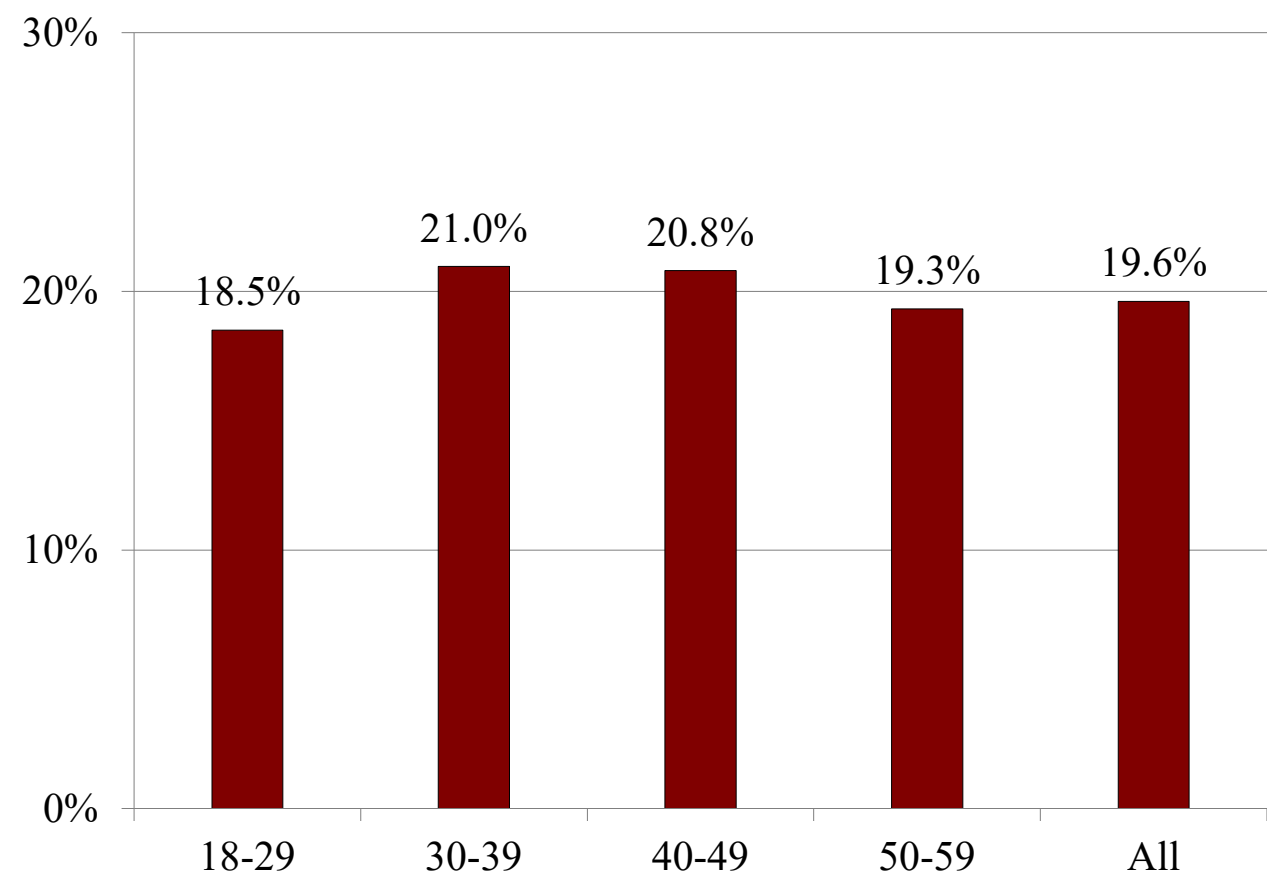

Source: Authors' calculations from OregonSaves' data. 


\section{RECENT WORKING PAPERS FROM THE CENTER FOR RETIREMENT RESEARCH AT BOSTON COLLEGE}

Why Are 401(k)/IRA Balances Substantially Below Potential?

Andrew G. Biggs, Alicia H. Munnell, and Anqi Chen, November 2019

How Best to Annuitize Defined Contribution Assets?

Alicia H. Munnell, Gal Wettstein, and Wenliang Hou, October 2019

How Do Older Workers Use Nontraditional Jobs?

Alicia H. Munnell, Geoffrey T. Sanzenbacher, and Abigail N. Walters, October 2019

Will More Workers Have Nontraditional Jobs as Globalization and Automation Spread?

Matthew S. Rutledge, Gal Wettstein, and Sara Ellen King, July 2019

Do States Adjust Medicaid Enrollment in Response to Capitation Rates? Evidence from the Medicare Part D Clawback

Laura D. Quinby and Gal Wettstein, June 2019

The Effect of Medicare Part D on Evergreening, Generic Entry, and Drug Prices

Geoffrey T. Sanzenbacher and Gal Wettstein, May 2019

Is the Drop in Fertility Due to The Great Recession or a Permanent Change?

Alicia H. Munnell, Anqi Chen, and Geoffrey T. Sanzenbacher, March 2019

Will Fewer Children Boost Demand for Formal Caregiving?

Gal Wettstein and Alice Zulkarnain, March 2019

The Relationship Between Occupational Requirements and SSDI Activity

Matthew S. Rutledge, Alice Zulkarnain, and Sara Ellen King, February 2019

How Does Contingent Work Affect SSDI Benefits?

Matthew S. Rutledge, Alice Zulkarnain, and Sara Ellen King, February 2019

Do Pension Cuts for Current Employees Increase Separation?

Laura D. Quinby and Gal Wettstein, January 2019

Competition, Asymmetric Information, and the Annuity Puzzle: Evidence from a Government-Run Exchange in Chile

Gastón Illanes and Manisha Padi, January 2019

All working papers are available on the Center for Retirement Research website (https://crr.bc.edu) and can be requested by e-mail (crr@bc.edu) or phone (617-552-1762). 